\title{
THE OLDEST ANTS ARE CRETACEOUS, NOT EOCENE: REPLY ${ }^{1}$
}

\author{
GEorge PoInAR ${ }^{2}$ \\ Department of Entomology, Oregon State University, Corvallis, Oregon, \\ United States 97331 \\ Cesare Baroni Urbani \\ Institut fur Natur-, Landschafts-und Umweltschutz, Abteilung Biogeographie, \\ Neuhausstrasse 31, CH-4057 Basel, Switzerland
}

and Alex Brown

629 Euclid Avenue, Berkeley, California, United States 94708

The Canadian Entomologist 132: 695 - 696 (2000)

Our study of the Hat Creek amber (Poinar et al. 1999) was undertaken to determine the range of the biota in the resin, to identify the plant that produced the resin, and to assess the future implications of these significant deposits. The study was in no way "compromised" by providing an alternative interpretation of the systematic position of the genus Sphecomyrma Wilson and Brown.

Grimaldi and Agosti (2000) present new interpretations of previously known data for establishing the genus Sphecomyrma in the family Formicidae. It is curious that Grimaldi et al. (1997) does not contain the data upon which their proposed ant phylogeny was based. In fact, the data was a modification of the original data matrix of Baroni Urbani et al. (1992). One of these "modifications" was eliminating the sole formicid synapomorphy contained in the original matrix, the length of the scape, which was a character that placed the genus Sphecomyrma outside the Formicidae. There are no other published definitions of the family Formicidae that are based on one or more synapomorphies and that allow for the inclusion or exclusion of critical taxa. In their present statements, the reasons given by Grimaldi and Agosti (2000) for placing the genus Sphecomyrma within the Formicidae are as follows.

(1) Presence of a metapleural gland. Unfortunately this is not a formicid synapomorphy because it is absent in a number of ant genera, including some of the basal formicid clades such as the genus Camponotus Mayr.

(2) A differentiated petiole. This character, which is not included in the data matrix by Grimaldi et al. (1997), cannot be considered a formicid synapomorphy because it is present in other hymenopteran families closely related to the Formicidae such as the Vespidae and Bradynobaenidae.

(3) Social behavior. This character, also omitted from the original data matrix by Grimaldi et al. (1997), cannot be supported on the present evidence of so few, separate fossils.

It should be noted that shortly after our paper (Poinar et al. 1999) was published, a paper by Rust and Andersen (1999) was published that described a new species of Pachycondyla F. Smith from the Fux and Olst formations (transitional between the Paleocene and Eocene) in Denmark. These authors also mentioned "the different

\footnotetext{
${ }_{1}^{1}$ Reply to Grimaldi D, Agosti D. 2000. The Canadian Entomologist 132: 691-3.

2 Author to whom all correspondence should be addressed (E-mail: poinarg@bcc.orst.edu).
} 
opinions on the systematic position of the Cretaceous ants" and regarded their early Tertiary ants as "one of the earliest records of true ants," thus making a distinction between true ants of the family Formicidae and the Cretaceous forms, including the genus Sphecomyrma.

We are not saying that Cretaceous ants do not exist, only that definite morphological types that can be placed in the present day genera have not yet been reported and that the fascinating genus Sphecomyrma share more characters with wasps than with ants of the family Formicidae.

Baroni Urbani C, Bolton B, Ward PS. 1992. The internal phylogeny of ants (Hymenoptera: Formicidae). Systematic Entomology 17: 137-68

Grimaldi D, Agosti D. 2000. The oldest ants are Cretaceous, not Eocene: comment. The Canadian Entomologist 132: 691-3

Grimaldi D, Agosti D, Carpenter JM. 1997. New and rediscovered primitive ants (Hymenoptera: Formicidae) in Cretaceous amber from New Jersey, and their phylogenetic relationships. American Museum Novitates 3208: $1-43$

Poinar G Jr., Archibald B, Brown A. 1999. New amber deposit provides evidence of early Paleogene extinctions, paleoclimates, and past distributions. The Canadian Entomologist 131: 171-7

Rust J, Andersen NM. 1999. Giant ants from the Paleogene of Denmark with a discussion of the fossil history and early evolution of ants (Hymenoptera: Fromicidae). Zoological Journal of the Linnean Society 125: $331-48$

(Date received: 20 September 2000; date accepted: 25 September 2000) 